ISSN 1678-3921

Journal homepage: www.embrapa.br/pab

For manuscript submission and journal contents, access: www.scielo.br/pab
Cristina Soethe $\mathrm{e}^{(1 \otimes)}(\mathrm{DD}$,

Cristiano André Steffens ${ }^{(1)}$ (ID,

Fernando José Hawerroth ${ }^{(2)}$ (iD,

Cassandro Vidal Talamini do Amarante ${ }^{(1)}$ (iD and Angélica Schmitz Heinzen ${ }^{(1)}$ (ID)

(1) Universidade do Estado de Santa Catarina, Centro de Ciências Agroveterinárias, Avenida Luiz de Camões, ㄲo 2.090, Conta Dinheiro, CEP 88520-000 Lages, SC, Brazil. E-mail: crisoethe@gmail.com, cristiano.steffens@udesc.br, cassandro.amarante.cav@udesc.br, angelica_heinzen@hotmail.com

(2) Embrapa Uva e Vinho, Estação Experimental de Fruticultura de Clima Temperado, BR 285, Km 115, Caixa Postal 177, CEP 95200-000 Vacaria, RS, Brazil. E-mail: fernando.hawerroth@embrapa.br

${ }^{凶}$ Corresponding author

Received

February 12, 2021

Accepted

July 21, 2021

How to cite

SOETHE, C.; STEFFENS, C.A.; HAWERROTH, F.J.; AMARANTE, C.V.T. do; HEINZEN,

A.S. Maturation of 'Baigent' apples protected by anti-hail nets and sprayed with aminoethoxyvinylglycine and ethephon. Pesquisa Agropecuária Brasileira, v.56, e02439, 2021. DOI: https://doi.org/10.1590/ S1678-3921.pab2021.v56.02439.

\section{Maturation of 'Baigent' apples protected by anti- hail nets and sprayed with aminoethoxyvinylglycine and ethephon}

\begin{abstract}
The objective of this work was to evaluate the effect of pre-harvest spraying with aminoethoxyvinylglycine (AVG) and ethephon on fruit maturation of 'Baigent' apple (Malus domestica) trees grown under black anti-hail nets. The treatments were: control; $125 \mathrm{mg} \mathrm{L}^{-1} \mathrm{AVG}$, sprayed 30 days before anticipated harvest time (DBAH); $120 \mathrm{mg} \mathrm{L}^{-1}$ ethephon $7 \mathrm{DBAH} ; 62.5$ $\mathrm{mg} \mathrm{L}^{-1}+62.5 \mathrm{mg} \mathrm{L}^{-1}$ AVG 30 and $20 \mathrm{DBAH}$; and $62.5 \mathrm{mg} \mathrm{L}^{-1}+62.5 \mathrm{mg} \mathrm{L}^{-1}$ AVG 30 and $20 \mathrm{DBAH}+120 \mathrm{mg} \mathrm{L}^{-1}$ ethephon 7 DBAH. Fruit were harvested in the commercial harvest of the control treatment (harvest 1 ) and 14 days later (harvest 2). Yellowing and loss of firmness were delayed by the treatments with AVG and accelerated by that with ethephon. AVG application in a single rate of $125 \mathrm{mg} \mathrm{L}^{-1} 30 \mathrm{DBAH}$ or in two split rates of $62.5 \mathrm{mg} \mathrm{L}^{-1} 30$ and 20 DBAH delays fruit maturation. The pre-harvest application of AVG in a single rate reduces the red color of the fruits, which is not affected by application in split rates, combined or not with ethephon, regardless of the date of harvest.
\end{abstract}

Index terms: Malus domestica, ethylene, fruit harvest management, plant growth regulators, shading.

\section{Maturação de maçãs 'Baigent' produzidas sob tela antigranizo e pulverizadas com aminoetoxivinilglicina e etefon}

Resumo - O objetivo deste trabalho foi avaliar o efeito da pulverização pré-colheita com aminoetoxivinilglicina (AVG) e etefon sobre a maturação dos frutos de macieiras 'Baigent' (Malus domestica) produzidas sob tela antigranizo preta. Os tratamentos foram: controle; $125 \mathrm{mg} \mathrm{L}^{-1}$ de AVG, aplicados 30 dias antes da colheita dos frutos não tratados (DAPC); 120 $\mathrm{mg} \mathrm{L}^{-1}$ de etefon 7 DAPC; $62,5 \mathrm{mg} \mathrm{L}^{-1}+62,5 \mathrm{mg} \mathrm{L}^{-1}$ de AVG 30 e 20 DAPC; e $62,5 \mathrm{mg} \mathrm{L}^{-1}+62,5 \mathrm{mg} \mathrm{L}^{-1}$ de AVG 30 e 20 DAPC $+120 \mathrm{mg} \mathrm{L}^{-1}$ de etefon 7 DAPC. Os frutos foram colhidos na colheita comercial do tratamento-controle (colheita 1) e após 14 dias (colheita 2). O amarelecimento e a perda de firmeza foram retardados pelos tratamentos com AVG e acelerados pelo com etefon. A aplicação de AVG em dose única de $125 \mathrm{mg} \mathrm{L}^{-1} 30 \mathrm{DAPH}$ ou em duas doses de $62,5 \mathrm{mg} \mathrm{L}^{-1} 30$ e $20 \mathrm{DAPH}$ retarda a maturação dos frutos. A aplicação précolheita de AVG em dose única reduz a coloração vermelha dos frutos, que não é afetada pela aplicação em dose dividida, combinada ou não com etefon, independentemente da data de colheita.

Termos para indexação: Malus domestica, etileno, escalonamento da colheita, fitorreguladores de crescimento, sombreamento. 


\section{Introduction}

Apples (Malus domestica Borkh) are the most popular fruit grown in regions of temperate climate in terms of cultivated area and volume produced (Stanger et al., 2017). However, due to the high production and the short period the fruits naturally remain at the correct maturation stage (Brackmann et al., 2015a, $2015 \mathrm{~b}$ ), the adoption of technologies to increase the harvest period is necessary, rationalizing the use of labor and allowing the fruits to be harvested at the ideal point (Scolaro et al., 2015; Soethe et al., 2019). In this context, the application of growth regulators is an alternative to anticipate or delay fruit harvest and to reduce pre- and post-harvest losses (Steffens et al., 2006; Soethe et al., 2019).

The growth regulator aminoethoxyvinylglycine (AVG) is commercially sprayed on apple trees to increase the harvest period by delaying maturation through its inhibitory action on ethylene synthesis (Brackmann et al., 2014; Soethe et al., 2019). The application of AVG slows down the degradation of starch, as well as the loss of flesh firmness (Steffens et al., 2006), and can provide an increase in yield, due to a reduction in pre-harvest drop and an increase in average fruit mass (Hawerroth et al., 2011; Arseneault \& Cline 2016). However, the pre-harvest application of AVG, at the recommended rate of $124 \mathrm{mg} \mathrm{L}^{-1}$, reduces the development of the red skin color of 'Royal Gala' apples (Scolaro et al., 2015), damaging their visual aspect and depreciating the value of production.

Another plant growth regulator that can be used on apple trees to manage harvest time is ethephon, which is indicated to anticipate (hasten) apple ripening when applied alone (Brackmann et al., 2015a) and to improve the red color of the fruit epidermis of the Gala cultivar (Brighenti et al., 2017). In apple trees previously sprayed with AVG, the application of ethephon reduces the negative effect on the formation of the red skin color of the 'Gala' apple, without affecting the delay of ripeness (Steffens et al., 2006). However, ethephon can compromise the organoleptic quality of the fruits, especially causing a significant loss of flesh firmness (Brackmann et al., 2015a).

Currently, most apple orchards in the Southern region of Brazil are grown under anti-hail nets, which reduces the incidence of solar radiation on plants and, consequently, can be detrimental to fruit production and quality (Amarante et al., 2009). According to
Brglez Sever et al. (2015) and Mupambi et al. (2018), the anti-hail net, by altering the environment (light, temperature, relative humidity, and wind, for example), interferes with the vegetative and reproductive growth of the plant, as well as with fruit physiology. Therefore, the application of AVG on apples produced under an anti-hail net may show results different from those obtained in full sunlight.

The recommendation for AVG use is to apply it, in a single rate, four weeks before the start of harvest forecast (Yuan \& Carbaugh, 2007). However, multiple applications of AVG can provide the same benefits delay of maturation - as the application of AVG in a single rate, but without compromising the development of the red color of the fruits (Hawerroth et al., 2011). For this reason, it is important to assess the effects of the multiple application of AVG, in combination or not with ethephon, to maintain the efficiency of AVG in regulating the ripening process, without, however, affecting the development of fruit skin color.

The objective of this work was to evaluate the effect of pre-harvest spraying with AVG and ethephon on fruit maturation of 'Baigent' apple trees grown under black anti-hail nets.

\section{Materials and Methods}

The experiment was carried out in the 2014/2015 and 2015/2016 harvest seasons, in a commercial orchard of 'Baigent' apple (M. domestica) trees, covered with black anti-hail nets, located in the municipality of Vacaria, in the state of Rio Grande do Sul, Brazil $\left(50^{\circ} 42^{\prime} \mathrm{W}, 28^{\circ} 33^{\prime} \mathrm{S}\right.$, at $955 \mathrm{~m}$ of altitude).

The orchard was composed of seven-year-old trees, grafted on the M9 rootstock and spaced at $3.5 \times 0.45$ $\mathrm{m}$. The black anti-hail nets, with a mesh opening of $4 \times 7 \mathrm{~mm}$ and 25 to $35 \%$ photosynthetic active radiation, were installed in 2010.The soil of the experimental field is a Latossolo Bruno Alumínico, according to the Brazilian soil classification system (Santos et al., 2018), i.e., an Oxisol (Soil Survey Staff, 2010). According to Köppen-Geiger's classification, the climate is Cfb, with a constantly moist temperate and a mild summer. Data on temperature, monthly precipitation, and relative humidity during the experimental period are shown in Table 1.

The treatments were: control, consisting of plants sprayed with water, which was applied 30 days before 
anticipated harvest time (DBAH); a single rate of AVG (125 $\left.\mathrm{mg} \mathrm{L}^{-1}\right)$ applied $30 \mathrm{DBAH}$; ethephon (120 $\left.\mathrm{mg} \mathrm{L}^{-1}\right)$ applied 7 DBAH; split rates of AVG $\left(62.5 \mathrm{mg} \mathrm{L}^{-1}+\right.$ $62.5 \mathrm{mg} \mathrm{L}^{-1}$ ) applied 30 and $20 \mathrm{DBAH}$; and split rates of AVG (62.5 mg L-1 $\left.+62.5 \mathrm{mg} \mathrm{L}^{-1}\right)$ applied 30 and 20 $\mathrm{DBAH}+$ ethephon $\left(120 \mathrm{mg} \mathrm{L}^{-1}\right)$ applied $7 \mathrm{DBAH}$.

The sources of AVG (15\% active ingredient) and ethephon ( $24 \%$ active ingredient) were, respectively, ReTain (Valent BioSciences Corporation, Libertyville, IL, USA) and Ethrel (Lanxess Corporation, Charleston, $\mathrm{SC}, \mathrm{USA})$. The adhesive spreader at $0.05 \% \mathrm{v} / \mathrm{v}$ used in the treatments was Break Thru (Evonik Corporation, Hopewell, VA, USA). All treatments of both experiments were sprayed using a motorized knapsack sprayer, with three D-6 nozzles, at the equivalent volume of $1.000 \mathrm{~L} \mathrm{ha}^{-1}$.

To characterize the advance in fruit maturation, two harvests were carried: commercial harvest of the control treatment (harvest 1) and harvest 14 days later (harvest 2). The ethephon treatment $\left(120 \mathrm{mg} \mathrm{L}^{-1}\right.$ applied 7 DBAH) was evaluated only in the first harvest season.

The commercial harvest date forecast was based on the date of full flowering and on the commercial harvest point for 'Gala' apples, which usually occurs 117 days after full flowering (Argenta \& Mondardo, 1994). In the 2014/2015 season, harvests 1 and 2 were carried out, respectively, on February 2 and 16, 2015; and, in the 2015/2016 season, on February 5 and 19, 2016, respectively.

After each harvest, the fruits were evaluated for respiratory rates $\left(\mathrm{mg} \mathrm{CO} \mathrm{Cg}^{-1} \mathrm{~h}^{-1}\right)$ and ethylene production ( $\mu \mathrm{g}_{2} \mathrm{H}_{4} \mathrm{~kg}^{-1} \mathrm{~h}^{-1}$ ), flesh firmness $(\mathrm{N})$, texture [strength for skin rupture $(\mathrm{N})$ and flesh penetration $(\mathrm{N})$ ], iodine-starch index (scale from 1 to 5), soluble solids ( $\mathrm{SS},{ }^{\circ} \mathrm{Brix}$ ), titratable acidity (TA, percentage of malic acid), SS/TA ratio, color of the epidermis (hue angle), and red-color index (scale from 1 to 4$)$.

The methodology described in Soethe et al. (2019) was used to determine respiratory rates and ethylene

Table 1. Maximum, minimum and average temperatures, monthly precipitation, and maximum and minimum relative humidity (RH), according to the month and year of production, in the 2014/2015 and 2015/2016 harvest seasons ${ }^{(1)}$.

\begin{tabular}{|c|c|c|c|c|c|c|c|}
\hline Year & Month & $\begin{array}{c}\text { Maximum } \\
\text { temperature }\left({ }^{\circ} \mathrm{C}\right)\end{array}$ & $\begin{array}{c}\text { Minimum } \\
\text { temperature }\left({ }^{\circ} \mathrm{C}\right)\end{array}$ & $\begin{array}{c}\text { Average } \\
\text { temperature }\left({ }^{\circ} \mathrm{C}\right)\end{array}$ & $\begin{array}{c}\text { Monthly } \\
\text { precipitation (mm) }\end{array}$ & $\begin{array}{l}\text { Maximum } \\
\text { RH }(\%)\end{array}$ & $\begin{array}{c}\text { Maximum } \\
\text { RH (\%) }\end{array}$ \\
\hline & & & & 2014/2015 season & & & \\
\hline \multirow{5}{*}{2014} & August & 19.9 & 6.9 & 12.5 & 104.8 & 100.0 & 18.0 \\
\hline & September & 20.4 & 10.9 & 14.9 & 249.6 & 100.0 & 31.0 \\
\hline & October & 24.0 & 12.4 & 17.1 & 188.4 & 100.0 & 28.0 \\
\hline & November & 24.5 & 13.1 & 18.1 & 147.2 & 100.0 & 24.0 \\
\hline & December & 25.6 & 14.9 & 19.3 & 320.6 & 100.0 & 14.0 \\
\hline \multirow{4}{*}{2015} & January & 26.6 & 15.9 & 20.2 & 118.4 & 100.0 & 22.0 \\
\hline & February & 26.0 & 15.1 & 19.4 & 176.2 & 100.0 & 37.0 \\
\hline & March & 24.8 & 14.2 & 18.4 & 175.4 & 100.0 & 35.0 \\
\hline & April & 22.1 & 11.7 & 15.9 & 123.2 & 100.0 & 30.0 \\
\hline & \multicolumn{7}{|c|}{ 2015/2016 season } \\
\hline \multirow{5}{*}{2015} & August & 21.9 & 11.0 & 15.5 & 50.8 & 100.0 & 10.0 \\
\hline & September & 20.6 & 9.8 & 14.3 & 248.4 & 100.0 & 19.0 \\
\hline & October & 21.8 & 12.0 & 15.9 & 338.6 & 100.0 & 28.0 \\
\hline & November & 22.8 & 13.3 & 17.2 & 149.8 & 100.0 & 25.0 \\
\hline & December & 25.5 & 16.0 & 19.8 & 277.6 & 100.0 & 28.0 \\
\hline \multirow{4}{*}{2016} & January & 26.9 & 15.9 & 20.5 & 198.4 & 100.0 & 21.0 \\
\hline & February & 26.6 & 16.7 & 20.6 & 135.2 & 100.0 & 33.0 \\
\hline & March & 23.5 & 13.6 & 17.6 & 169.8 & 100.0 & 32.0 \\
\hline & April & 24.6 & 14.2 & 18.3 & 155.2 & 100.0 & 31.0 \\
\hline
\end{tabular}

(1)Data obtained from the A880 weather station of Instituto Nacional de Meteorologia, located in the municipality of Vacaria, in the state of Rio Grande do Sul, Brazil. 
production, flesh firmness, texture, SS, TA, and the $\mathrm{SS} / \mathrm{TA}$ ratio.

The iodine-starch index was obtained according to Stanger et al. (2017), using a scale of 1 (flesh cross-section stained by the starch-iodine complex, indicating a high starch content and unripe fruit) to 5 (flesh cross-section not stained by the starch-iodine complex, indicating a starch content close to zero and ripe fruit).

Hue angle $\left(h^{\circ}\right)$, a color-intensity indicator for determining color differences in fruits that ripen from green to either yellow or shades of red, was calculated with the aid of the CR 400 Minolta colorimeter (Konica Minolta, Tokyo, Japan) and expressed in degrees. The values of $h^{\circ}$ correspond to surface colors of the plant tissue, as follows: $0^{\circ}$, red; $90^{\circ}$, yellow; $180^{\circ}$, green; and $270^{\circ}$, blue (Soethe et al., 2019). Two measurements were performed in the equatorial regions of the fruits, one in the least red region and the other in the most red region.

The red-color index was determined using the methodology described in Steffens et al. (2006), with adaptations. Each fruit was individually evaluated in relation to the red color of their skin and classified according to an index scale from 1 to 4 , in which: index 1 indicates a red-pigmented surface equivalent to 0 to $25 \%$ of the total surface of the fruit; index 2 , from 26 to $50 \%$; index 3 , from 51 to $75 \%$; and index 4 , from 76 to $100 \%$. The index was obtained by multiplying the number of fruit classified in each index by the index number; then, the result of the sum of these multiplications was divided by the number of fruits assessed in each sample.

In the 2014/2015 season, the respiratory and ethylene production rates were evaluated only in the second harvest.

The experimental design was randomized complete blocks in a $5 \times 2$ factorial arrangement (five treatments $\mathrm{x}$ two harvest periods), with four replicates composed of 20 fruits each. The data were subjected to the analysis of variance, and means were compared by Tukey's test, at $5 \%$ probability, with the aid of the SAS software (SAS Institute Inc., Cary, NC, USA).

\section{Results and Discussion}

In the 2014/2015 harvest season, the ethylene production rate was reduced by the pre-harvest application of AVG in single or split rates, whether or not followed by the application of ethephon, but was increased with the application of only ethephon, also being high in the control treatment (Table 2). In the 2015/2016 season, there was an interaction between the factors pre-harvest treatments and harvest date; however, regardless of the harvest date, any form of pre-harvest application of AVG caused a lower rate of ethylene production than the control. Likewise, Ozturk et al. (2015) found a reduction in the ethylene production rate in 'Jonagold' apple sprayed with AVG in single and split rates of $225 \mathrm{~mL}^{-1}$. AVG blocks the production of 1-aminocyclopropane-1-carboxylate (ACC), by inhibiting its synthase, reducing the production of ethylene in the fruit (Wendt et al., 2020). However, ethephon, when releasing ethylene, promotes the autocatalytic production of this phytohormone (Steffens et al., 2006).

Despite this, in both seasons, the application of ethephon on plants previously sprayed with AVG did not increase ethylene production, when compared with the treatments with AVG only (Table 2). Steffens et al. (2006) observed a similar result with the combined use of these two substances on 'Gala' apples. As for harvest date, only the fruits of the control treatment showed an increase in ethylene production with the delay in harvesting.

The respiration rate in the 2014/2015 season was lower in the fruits of the plants that received only the application of AVG in single or split rates, when compared with those under the control treatment (Table 2). However, fruits of the plants treated preharvest with ethephon, combined or not with AVG, did not differ from those of the other treatments. In the 2015/2016 season, only the fruits that received the application of AVG in a single rate showed a lower respiratory rate than those subjected to the control, while those of the other treatments did not differ from one another. The lowest respiration rate measured in that treatment is probably related to the lowest ethylene production observed in fruits sprayed with AVG due to the close relationship between both of these variables (Both et al., 2016).

In the 2014/2015 season, there was an interaction between the pre-harvest treatment and harvest date for the iodine-starch index (Table 3). In the first harvest, fruits from the plants sprayed with split rates of AVG showed a lower index, followed by those treated with 
the single rate of AVG, while fruits under the control treatment had a higher index. Moreover, the application of ethephon resulted in a lower iodine-starch index only with the split rates of AVG. In the second harvest, there was no difference between the pre-harvest treatments for this variable. However, the application of AVG, regardless of the used form, provided fruits with a lower index, compared with the control. Hawerroth et al. (2011) also found a lower iodinestarch index for 'Imperial Gala' fruits that received a pre-harvest application of $\mathrm{AVG}$, both in single (120 $\left.\mathrm{g} \mathrm{ha}^{-1} 30 \mathrm{DBAH}\right)$ and split $\left(60 \mathrm{~g} \mathrm{ha}^{-1} 30 \mathrm{DBAH}\right.$ $\left.+60 \mathrm{~g} \mathrm{ha}^{-1} 20 \mathrm{DBAH}\right)$ rates, considering that starch degradation is a direct consequence of the induction caused by ethylene. In another study, the starch content was higher in fruits that received AVG application, which probably culminated in lower SS since starch molecules are converted into monosaccharides during fruit maturation (Brackmann et al., 2015a).

In the 2014/2015 season, SS content was lower with the pre-harvest application of AVG in a single rate, but higher with only the application of ethephon (Table 3). In addition, there was no difference between the split application of AVG, combined or not with ethephon, and the control treatment. In the 2015/2016 season, the fruits that received a pre-harvest application of AVG in single or split rates had a lower SS content, followed by those subjected to the split application of AVG combined with ethephon, while the fruits of the control treatment showed higher SS values. A lower concentration of SS in 'Gala' apples sprayed with AVG was also reported by Petri et al. (2010), who used a single rate of AVG, and by Hawerroth et al. (2011), who applied AVG in single (120 $\left.\mathrm{g} \mathrm{ha}^{-1} 30 \mathrm{DBAH}\right)$ and split (60 $\mathrm{g} \mathrm{ha}^{-1} 30 \mathrm{DBAH}+$ $60 \mathrm{~g} \mathrm{ha}^{-1} 14 \mathrm{DBAH}$ ) rates. The observed response may be associated with a lower starch hydrolysis in apples sprayed with AVG due to a reduction in the ethylene production rate (Brackmann et al., 2015a). According to Steffens et al. (2011), high SS values may be related to a high content of soluble pectins, since those fruits had the lowest pulp firmness and a lower pulp penetration and skin rupture strength (Table 4), showing their faster maturation in the control treatment.

In the 2014/2015 season, the pre-harvest application of AVG, in single or split rates, combined or not with ethephon, resulted in fruits with higher TA values,

Table 2. Ethylene production and respiration rates of fruits of 'Baigent' apple (Malus domestica) trees treated with the pre-harvest application of aminoethoxyvinilglycine (AVG) and ethephon, and harvested on two dates ${ }^{(1)}$.

\begin{tabular}{|c|c|c|c|c|c|}
\hline \multirow[t]{2}{*}{ Treatment } & \multicolumn{2}{|c|}{$2014 / 2015$ season } & \multicolumn{2}{|c|}{$2015 / 2016$ season } & \multirow[t]{2}{*}{ Average } \\
\hline & Harvest 1 & Harvest 2 & Harvest 1 & Harvest 2 & \\
\hline & \multicolumn{5}{|c|}{ Ethylene production rate $\left(\mu \mathrm{g} \mathrm{C}_{2} \mathrm{H}_{4} \mathrm{~kg}^{-1} \mathrm{~h}^{-1}\right)$} \\
\hline Control & - & $55.0 \mathrm{~A}$ & $0.3 \mathrm{Ab}$ & $2.5 \mathrm{Aa}$ & - \\
\hline $125 \mathrm{mg} \mathrm{L}^{-1} \mathrm{AVG} 30 \mathrm{DBAH}$ & - & $13.3 \mathrm{~B}$ & $0.0 \mathrm{Ba}$ & $0.1 \mathrm{Ba}$ & - \\
\hline $120 \mathrm{mg} \mathrm{L}^{-1}$ ethephon $7 \mathrm{DBAH}$ & - & $70.3 \mathrm{~A}$ & - & - & - \\
\hline $62.5 \mathrm{mg} \mathrm{L}^{-1} \mathrm{AVG} 30 \mathrm{DBAH}+62.5 \mathrm{mg} \mathrm{L}^{-1} \mathrm{AVG} 20 \mathrm{DBAH}$ & - & $8.8 \mathrm{~B}$ & $0.1 \mathrm{Ba}$ & $0.2 \mathrm{Ba}$ & - \\
\hline $\begin{array}{l}62.5 \mathrm{mg} \mathrm{L}^{-1} \mathrm{AVG} 30 \mathrm{DBAH}+62.5 \mathrm{mg} \mathrm{L}^{-1} \mathrm{AVG} 20 \mathrm{DBAH}+ \\
120 \mathrm{mg} \mathrm{L}^{-1} \text { ethephon } 7 \text { DBAH }\end{array}$ & - & $11.5 \mathrm{~B}$ & $0.0 \mathrm{Ba}$ & $0.5 \mathrm{Ba}$ & - \\
\hline Average & - & - & & & \\
\hline \multirow[t]{2}{*}{ Coefficient of variation (\%) } & & 35.2 & & & \\
\hline & \multicolumn{5}{|c|}{ Respiratory rate $\left(\mathrm{mg} \mathrm{CO}_{2} \mathrm{~kg}^{-1} \mathrm{~h}^{-1}\right)$} \\
\hline Control & - & $19.6 \mathrm{~A}$ & 19.7 & 15.0 & $17.4 \mathrm{~A}$ \\
\hline $125 \mathrm{mg} \mathrm{L}^{-1} \mathrm{AVG} 30 \mathrm{DBAH}$ & - & $12.7 \mathrm{~B}$ & 14.5 & 15.3 & 14.9B \\
\hline $120 \mathrm{mg} \mathrm{L}^{-1}$ ethephon $7 \mathrm{DBAH}$ & - & $15.6 \mathrm{AB}$ & - & - & - \\
\hline $62.5 \mathrm{mg} \mathrm{L}^{-1} \mathrm{AVG} 30 \mathrm{DBAH}+62.5 \mathrm{mg} \mathrm{L}^{-1} \mathrm{AVG} 20 \mathrm{DBAH}$ & - & 13.4B & 15.2 & 16.3 & $15.8 \mathrm{AB}$ \\
\hline $\begin{array}{l}62.5 \mathrm{mg} \mathrm{L}^{-1} \mathrm{AVG} 30 \mathrm{DBAH}+62.5 \mathrm{mg} \mathrm{L}^{-1} \mathrm{AVG} 20 \mathrm{DBAH}+ \\
120 \mathrm{mg} \mathrm{L}^{-1} \text { ethephon } 7 \text { DBAH }\end{array}$ & - & $14.5 \mathrm{AB}$ & 15.4 & 16.4 & $15.9 \mathrm{AB}$ \\
\hline Average & - & - & $16.2 \mathrm{a}$ & $15.8 \mathrm{a}$ & \\
\hline Coefficient of variation (\%) & & 9.3 & & & \\
\hline
\end{tabular}


when compared with the control treatment; however, the isolated pre-harvest application of ethephon did not differ from the control (Table 3). In fruits sprayed with AVG, the highest TA is related to the lowest respiratory rate, since organic acids are consumed in the tricarboxylic acid cycle (Steffens et al., 2007). In the 2015/2016 season, TA did not differ between
AVG treatments, combined or not with ethephon, and the control. It should be noted that the SS/AT ratio represents the balance between the contents of acids and sugars in fruits, conditioned by the balance between taste and aroma (Munaretto et al., 2018). Regarding this ratio, there was no effect of pre-harvest treatments in both seasons.

Table 3. Iodine-starch index, soluble solids, titratable acidity, and soluble solids/titratable acidity ratio of fruits of 'Baigent' apple (Malus domestica) trees treated with the pre-harvest application of aminoethoxyvinilglycine (AVG) and ethephon, and harvested on two dates ${ }^{(1)}$.

\begin{tabular}{|c|c|c|c|c|c|c|}
\hline \multirow[t]{2}{*}{ Treatment } & \multicolumn{2}{|c|}{$2014 / 2015$ season } & \multirow[t]{2}{*}{ Average } & \multicolumn{2}{|c|}{$2015 / 2016$ season } & \multirow[t]{2}{*}{ Average } \\
\hline & Harvest 1 & Harvest 2 & & Harvest 1 & Harvest 2 & \\
\hline & \multicolumn{6}{|c|}{ Iodine-starch index (1 to 5) } \\
\hline Control & $4.5 \mathrm{Ab}$ & $5.0 \mathrm{Aa}$ & - & 3.3 & 4.7 & $4.0 \mathrm{~A}$ \\
\hline $125 \mathrm{mg} \mathrm{L}^{-1}$ AVG $30 \mathrm{DBAH}$ & $4.0 \mathrm{Bb}$ & 4.9Aa & - & 2.9 & 3.6 & $3.2 \mathrm{~B}$ \\
\hline $120 \mathrm{mg} \mathrm{L}^{-1}$ ethephon 7 DBAH & $4.5 \mathrm{ABb}$ & $5.0 \mathrm{Aa}$ & - & - & - & - \\
\hline $62.5 \mathrm{mg} \mathrm{L}^{-1} \mathrm{AVG} 30 \mathrm{DBAH}+62.5 \mathrm{mg} \mathrm{L}^{-1} \mathrm{AVG} 20 \mathrm{DBAH}$ & $3.4 \mathrm{Cb}$ & 4.9Aa & - & 2.7 & 3.3 & $3.0 \mathrm{~B}$ \\
\hline $\begin{array}{l}62.5 \mathrm{mg} \mathrm{L}^{-1} \text { AVG } 30 \mathrm{DBAH}+62.5 \mathrm{mg} \mathrm{L}^{-1} \text { AVG } 20 \mathrm{DBAH}+120 \\
\mathrm{mg} \mathrm{L}^{-1} \text { ethephon } 7 \text { DBAH }\end{array}$ & $4.3 \mathrm{ABb}$ & $5.0 \mathrm{Aa}$ & - & 3.5 & 3.6 & $3.5 \mathrm{AB}$ \\
\hline Average & - & - & & $3.1 \mathrm{~b}$ & $3.9 \mathrm{a}$ & \\
\hline \multirow[t]{2}{*}{ Coefficient of variation $(\%)$} & \multicolumn{2}{|c|}{3.3} & \multicolumn{4}{|c|}{12.1} \\
\hline & \multicolumn{6}{|c|}{ Soluble solids $\left({ }^{\circ}\right.$ Brix $)$} \\
\hline Control & 10.8 & 11.9 & $11.4 \mathrm{AB}$ & 11.8 & 12.2 & $12.0 \mathrm{~A}$ \\
\hline $125 \mathrm{mg} \mathrm{L}^{-1}$ AVG 30 DBAH & 10.5 & 11.9 & $11.2 \mathrm{~B}$ & 10.2 & 10.6 & $10.4 \mathrm{C}$ \\
\hline $120 \mathrm{mg} \mathrm{L}^{-1}$ ethephon 7 DBAH & 11.4 & 12.5 & $11.9 \mathrm{~A}$ & - & - & - \\
\hline $62.5 \mathrm{mg} \mathrm{L}^{-1} \mathrm{AVG} 30 \mathrm{DBAH}+62.5 \mathrm{mg} \mathrm{L}^{-1} \mathrm{AVG} 20 \mathrm{DBAH}$ & 10.6 & 12.0 & $11.3 \mathrm{AB}$ & 10.0 & 11.0 & $10.5 \mathrm{C}$ \\
\hline $\begin{array}{l}62.5 \mathrm{mg} \mathrm{L}^{-1} \mathrm{AVG} 30 \mathrm{DBAH}+62.5 \mathrm{mg} \mathrm{L}^{-1} \mathrm{AVG} 20 \mathrm{DBAH}+120 \\
\mathrm{mg} \mathrm{L}^{-1} \text { ethephon } 7 \text { DBAH }\end{array}$ & 10.7 & 12.0 & $11.2 \mathrm{AB}$ & 10.6 & 11.9 & $11.3 \mathrm{~B}$ \\
\hline Average & $10.8 \mathrm{~b}$ & $12.0 \mathrm{a}$ & & $10.7 \mathrm{~b}$ & $11.4 \mathrm{a}$ & \\
\hline \multirow[t]{2}{*}{ Coefficient of variation $(\%)$} & \multicolumn{2}{|c|}{4.4} & \multicolumn{4}{|c|}{4.1} \\
\hline & \multicolumn{6}{|c|}{ Titratable acidity ( $\%$ malic acid) } \\
\hline Control & 0.193 & 0.191 & $0.192 \mathrm{~B}$ & 0.189 & 0.165 & $0.177 \mathrm{~ns}$ \\
\hline $125 \mathrm{mg} \mathrm{L}^{-1}$ AVG $30 \mathrm{DBAH}$ & 0.209 & 0.202 & $0.206 \mathrm{~A}$ & 0.161 & 0.144 & 0.153 \\
\hline $120 \mathrm{mg} \mathrm{L}^{-1}$ ethephon 7 DBAH & 0.205 & 0.200 & $0.202 \mathrm{AB}$ & - & - & - \\
\hline $62.5 \mathrm{mg} \mathrm{L}^{-1} \mathrm{AVG} 30 \mathrm{DBAH}+62.5 \mathrm{mg} \mathrm{L}^{-1} \mathrm{AVG} 20 \mathrm{DBAH}$ & 0.211 & 0.198 & $0.205 \mathrm{~A}$ & 0.176 & 0.159 & 0.167 \\
\hline $\begin{array}{l}62.5 \mathrm{mg} \mathrm{L}^{-1} \mathrm{AVG} 30 \mathrm{DBAH}+62.5 \mathrm{mg} \mathrm{L}^{-1} \mathrm{AVG} 20 \mathrm{DBAH}+120 \\
\mathrm{mg} \mathrm{L}^{-1} \text { ethephon } 7 \text { DBAH }\end{array}$ & 0.215 & 0.191 & $0.203 \mathrm{~A}$ & 0.181 & 0.172 & 0.177 \\
\hline Average & $0.207 \mathrm{a}$ & $0.196 b$ & & $0.177 \mathrm{a}$ & $0.160 \mathrm{~b}$ & \\
\hline \multirow[t]{2}{*}{ Coefficient of variation (\%) } & \multicolumn{2}{|c|}{3.50} & \multicolumn{4}{|c|}{8.68} \\
\hline & \multicolumn{6}{|c|}{ Soluble solids/titratable acidity } \\
\hline Control & 56.0 & 62.7 & $59.4^{\mathrm{ns}}$ & 62.9 & 75.2 & $69.0^{\mathrm{ns}}$ \\
\hline $125 \mathrm{mg} \mathrm{L}^{-1} \mathrm{AVG} 30 \mathrm{DBAH}$ & 49.7 & 57.7 & 53.9 & 63.6 & 73.7 & 68.6 \\
\hline $120 \mathrm{mg} \mathrm{L}^{-1}$ ethephon $7 \mathrm{DBAH}$ & 54.9 & 62.4 & 59.2 & - & - & - \\
\hline $62.5 \mathrm{mg} \mathrm{L}^{-1} \mathrm{AVG} 30 \mathrm{DBAH}+62.5 \mathrm{mg} \mathrm{L}^{-1} \mathrm{AVG} 20 \mathrm{DBAH}$ & 50.2 & 61.7 & 55.1 & 56.8 & 69.2 & 63.0 \\
\hline $\begin{array}{l}62.5 \mathrm{mg} \mathrm{L}^{-1} \mathrm{AVG} 30 \mathrm{DBAH}+62.5 \mathrm{mg} \mathrm{L}^{-1} \mathrm{AVG} 20 \mathrm{DBAH}+120 \\
\mathrm{mg} \mathrm{L}^{-1} \text { ethephon } 7 \text { DBAH }\end{array}$ & 49.8 & 62.6 & 55.2 & 59.1 & 69.2 & 64.1 \\
\hline Average & $52.0 \mathrm{~b}$ & $61.5 \mathrm{a}$ & & $60.6 \mathrm{~b}$ & $71.8 \mathrm{a}$ & \\
\hline Coefficient of variation $(\%)$ & \multicolumn{2}{|c|}{6.2} & \multicolumn{4}{|c|}{8.0} \\
\hline
\end{tabular}

${ }^{(1)}$ Values followed by equal letters, uppercase in the columns and lowercase in the lines, do not differ by Tukey's test, at 5\% probability. DBAH, days before anticipated harvest time. Harvest 1, commercial harvest of the control treatment. Harvest 2, 14 days after commercial harvest of the control treatment. -, data not obtained. ns Nonsignificant difference. 
In the 2014/2015 season, any form of pre-harvest application of AVG (single or split rates) provided fruits with a higher flesh firmness, compared with the other treatments (Table 4). However, in the 2015/2016 season, there was no effect of pre-harvest treatments on this attribute. Scolaro et al. (2015) and Yildiz et al. (2012) also observed a higher flesh firmness in 'Royal Gala' and 'Red Chief' apples, respectively, that received a pre-harvest application of AVG, when compared with the control. The higher flesh firmness found in fruits sprayed with AVG may be related to the lower rates of ethylene production and respiration, as well as to the lower activity of ACC oxidase (Wendt et al., 2020). However, this variation in results between years of production may also be related to the stage of fruit maturation at harvest, fruit position on the canopy, and the different environmental conditions during the crop cycle (Drogoudi \& Pantelidis, 2011; Zheng et al., 2012).

In the 2014/2015 season, there was no treatment effect for strength for flesh penetration (Table 4). However, in the 2015/2016 season, compared with the control treatment, all forms of pre-harvest application of AVG resulted in fruits with a greater strength for flesh penetration. For strength for skin rupture, in the 2014/2015 season, higher values were obtained for fruits that received all forms of pre-harvest application of AVG, as well as only the application of ethephon. However, in the 2015/2016 season, there was no treatment effect for strength for skin rupture. According to Guillermin et al. (2006), the consistency of the flesh

Table 4. Flesh firmness and strength for skin rupture and flesh penetration of fruits of 'Baigent' apple (Malus domestica) trees treated with the pre-harvest application of aminoethoxyvinilglycine (AVG) and ethephon, and harvested on two dates ${ }^{(1)}$.

\begin{tabular}{|c|c|c|c|c|c|c|}
\hline \multirow[t]{2}{*}{ Treatment } & \multicolumn{2}{|c|}{$2014 / 2015$ season } & \multirow[t]{2}{*}{ Average } & \multicolumn{2}{|c|}{$2015 / 2016$ season } & \multirow[t]{2}{*}{ Average } \\
\hline & Harvest 1 & Harvest 2 & & Harvest 1 & Harvest 2 & \\
\hline & \multicolumn{6}{|c|}{ Flesh firmness (N) } \\
\hline Control & 70.7 & 57.2 & $64.0 \mathrm{~B}$ & 81.2 & 69.8 & $74.2^{\mathrm{ns}}$ \\
\hline $125 \mathrm{mg} \mathrm{L}^{-1}$ AVG $30 \mathrm{DBAH}$ & 74.8 & 60.3 & $67.6 \mathrm{~A}$ & 79.1 & 73.7 & 76.4 \\
\hline $120 \mathrm{mg} \mathrm{L}^{-1}$ ethephon 7 DBAH & 72.0 & 56.8 & $64.4 \mathrm{~B}$ & - & - & - \\
\hline $62.5 \mathrm{mg} \mathrm{L}^{-1} \mathrm{AVG} 30 \mathrm{DBAH}+62.5 \mathrm{mg} \mathrm{L}^{-1} \mathrm{AVG} 20 \mathrm{DBAH}$ & 75.3 & 62.0 & $68.7 \mathrm{~A}$ & 76.1 & 74.2 & 75.2 \\
\hline $\begin{array}{l}62.5 \mathrm{mg} \mathrm{L}^{-1} \text { AVG } 30 \mathrm{DBAH}+62.5 \mathrm{mg} \mathrm{L}^{-1} \mathrm{AVG} 20 \mathrm{DBAH} \\
+120 \mathrm{mg} \mathrm{L}^{-1} \text { ethephon } 7 \mathrm{DBAH}\end{array}$ & 75.1 & 60.6 & $68.9 \mathrm{~A}$ & 76.7 & 76.3 & 76.5 \\
\hline Average & $73.6 \mathrm{a}$ & $59.3 b$ & & $77.9 \mathrm{a}$ & $73.4 b$ & \\
\hline \multirow[t]{2}{*}{ Coefficient of variation $(\%)$} & \multicolumn{2}{|c|}{3.2} & \multicolumn{4}{|c|}{4.2} \\
\hline & \multicolumn{6}{|c|}{ Strength for flesh penetration $(\mathrm{N})$} \\
\hline Control & 3.3 & 2.6 & $2.9^{\text {ns }}$ & 3.7 & 3.1 & 3.4B \\
\hline $125 \mathrm{mg} \mathrm{L}^{-1}$ AVG $30 \mathrm{DBAH}$ & 3.5 & 2.7 & 3.1 & 3.9 & 3.6 & $3.8 \mathrm{~A}$ \\
\hline $120 \mathrm{mg} \mathrm{L}^{-1}$ ethephon $7 \mathrm{DBAH}$ & 3.3 & 2.6 & 3.0 & - & - & - \\
\hline $62.5 \mathrm{mg} \mathrm{L}^{-1} \mathrm{AVG} 30 \mathrm{DBAH}+62.5 \mathrm{mg} \mathrm{L}^{-1} \mathrm{AVG} 20 \mathrm{DBAH}$ & 3.7 & 2.7 & 3.2 & 3.9 & 3.6 & $3.8 \mathrm{~A}$ \\
\hline $\begin{array}{l}62.5 \mathrm{mg} \mathrm{L}^{-1} \mathrm{AVG} 30 \mathrm{DBAH}+62.5 \mathrm{mg} \mathrm{L}^{-1} \mathrm{AVG} 20 \mathrm{DBAH} \\
+120 \mathrm{mg} \mathrm{L}^{-1} \text { ethephon } 7 \text { DBAH }\end{array}$ & 3.5 & 2.7 & 3.1 & 3.7 & 3.7 & $3.7 \mathrm{~A}$ \\
\hline Average & $3.5 \mathrm{a}$ & $2.6 \mathrm{~b}$ & & $3.8 \mathrm{a}$ & $3.5 \mathrm{~b}$ & \\
\hline \multirow[t]{2}{*}{ Coefficient of variation $(\%)$} & \multicolumn{2}{|c|}{6.4} & \multicolumn{4}{|c|}{4.5} \\
\hline & \multicolumn{6}{|c|}{ Strength for skin rupture $(\mathrm{N})$} \\
\hline Control & 12.1 & 11.0 & $11.6 \mathrm{~B}$ & 13.8 & 12.4 & $13.1^{\mathrm{ns}}$ \\
\hline $125 \mathrm{mg} \mathrm{L}^{-1} \mathrm{AVG} 30 \mathrm{DBAH}$ & 12.9 & 11.7 & $12.3 \mathrm{~A}$ & 13.8 & 13.3 & 13.6 \\
\hline $120 \mathrm{mg} \mathrm{L}^{-1}$ ethephon $7 \mathrm{DBAH}$ & 12.3 & 11.9 & $12.1 \mathrm{~A}$ & - & - & - \\
\hline $62.5 \mathrm{mg} \mathrm{L}^{-1}$ AVG $30 \mathrm{DBAH}+62.5 \mathrm{mg} \mathrm{L}^{-1}$ AVG $20 \mathrm{DBAH}$ & 12.8 & 12.4 & $12.6 \mathrm{~A}$ & 13.2 & 12.9 & 13.1 \\
\hline $\begin{array}{l}62.5 \mathrm{mg} \mathrm{L}^{-1} \mathrm{AVG} 30 \mathrm{DBAH}+62.5 \mathrm{mg} \mathrm{L}^{-1} \mathrm{AVG} 20 \mathrm{DBAH} \\
+120 \mathrm{mg} \mathrm{L}^{-1} \text { ethephon } 7 \text { DBAH }\end{array}$ & 12.8 & 12.0 & $12.4 \mathrm{~A}$ & 14.1 & 12.9 & 13.5 \\
\hline Average & $12.6 \mathrm{a}$ & $11.8 \mathrm{~b}$ & & $13.7 \mathrm{a}$ & $12.8 \mathrm{~b}$ & \\
\hline Coefficient of variation (\%) & \multicolumn{2}{|c|}{2.9} & \multicolumn{4}{|c|}{13.1} \\
\hline
\end{tabular}

(1)Values followed by equal letters, uppercase in the columns and lowercase in the lines, do not differ by Tukey's test, at 5\% probability. DBAH, days before anticipated harvest time. Harvest 1, commercial harvest of the control treatment. Harvest 2, 14 days after commercial harvest of the control

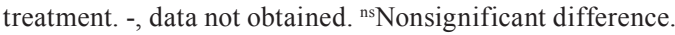


and the resistance of the epidermis may show different behaviors, as observed in the present study, since the resistance of the epidermal tissue undergoes less variation with the advance of maturation, protecting the internal tissue against the disintegration of cells. It is likely that the higher ethylene production rate of the fruits of the control and ethephon treatments resulted in a lower firmness of the flesh due to an increase in the metabolism and activity of cell-wall enzymes (Brackmann et al., 2015a, 2015b).

For the $h^{\circ}$ in the most red region of the apple, in the first season, there was an interaction between the pre-harvest treatment and harvest date (Table 5). In the first harvest, the pre-harvest split application of AVG, combined or not with ethephon, provided fruits with a lower intensity of the red color (higher $h^{\circ}$ in the most red region). The lowest values of $h^{\circ}$ were measured in the fruits of the plants subjected to ethephon application and the control. With the delay in harvest date, all treatments increased the intensity of the red color, except the single rate of AVG. In the second harvest (late harvest), the intensity of fruit red color was lower with the pre-harvest application of AVG in a single rate, but higher with the pre-harvest application of ethephon and the control treatment. The pre-harvest split application of AVG, combined or not with ethephon, resulted in intermediate values of $h^{\circ}$, not differing from the other treatments. With the delay in harvest date, all treatments increased the intensity of the red color of the fruits, except the application of AVG in a single rate.

In the 2015/2016 season, the pre-harvest application of AVG in a single rate provided fruits with a lower intensity of the red color in the epidermis, without differing from the pre-harvest split application of AVG, combined or not with ethephon, which did not differ from the control treatment (Table 5). These results are in agreement with those of Ozkan et al. (2012), who found a delay in the development of the red color in the epidermis of 'Braeburn' apples sprayed with a single rate of AVG. Ozturk et al. (2015) reported that the application of AVG in a single rate resulted in a less intense red color in the epidermis of 'Jonagold' apple than split rates.

In relation to the least red region of the fruits, in the 2014/2015 season, higher values of $h^{\circ}$ were obtained with the pre-harvest application of AVG in a single rate, that is, the fruits of this treatment had a greener background color than those subjected to the other treatments (Table 5). In the 2015/2016 season, any form of AVG application (single or split rates, combined or not with ethephon) lead to higher values of $h^{\circ}$ of the background color of the epidermis. The lower yellowing of the skin may also be associated with the reduction of ethylene production in fruits sprayed with AVG, reducing the activity of the chlorophyllase and peroxidase enzymes, which act in the degradation of chlorophylls (Whale \& Singh, 2007).

For the red-color index variable, in the two evaluated seasons, the split application of AVG, combined or not with ethephon, did not reduce the surface of the fruit covered with the red color (Table 5). However, fruits sprayed with AVG in a single rate showed lower values for the index than those sprayed with only ethephon and the control treatment, which did not differ from the other AVG treatments. Scolaro et al. (2015) also found a reduction in the percentage of the red skin color of 'Royal Gala' apples sprayed with AVG in a single rate of $124 \mathrm{mg} \mathrm{L}^{-1}$. The reduced development and intensity of the red skin color of fruits sprayed with a single rate of AVG may be related to the lower ethylene production rate compared with the control treatment. According to Awad \& Jager (2002), ethylene triggers the expression of genes from the biosynthesis of anthocyanins, because it leads to the activation of a secondary metabolism, as a result of the increased activity of the phenylalanine ammonialyase enzyme, conferring a red skin color to the fruit, whereas AVG inhibits or delays the expression of the phytohormone due to a reduction in the rate of ethylene production and, consequently, a lower concentration of anthocyanins in the fruit. This effect can be even more significant in crops under anti-hail nets, considering the reduction in light, which compromises the synthesis of anthocyanins (Mupambi et al., 2018).

Therefore, the development of the red skin color was negatively affected by the anti-hail nets and the preharvest application of AVG, as reported for 'Braeburn' (Ozkan et al., 2012) and 'Royal Gala' (Scolaro et al., 2015) apples subjected to this same treatment but under full sunlight. However, there was no detrimental effect of AVG on the development of the red color of 'Brookfield' apples, a clone with an intense red color in the epidermis, also in full sunlight (Brackmann et al., 2015b). In the case of 'Baigent' apples grown under anti-hail nets, there may have been a greater reduction

Pesq. agropec. bras., Brasília, v.56, e02439, 2021

DOI: 10.1590/S1678-3921.pab2021.v56.02439 
in the development of the red skin color in response to AVG application, as the quantity and quality of light that affects the fruits were reduced.

In the present work, in one of the study years, even with the delay of 14 days in harvest, there was no substantial evolution in the development of the red color of fruits from plants sprayed with a single rate of AVG. This shows that the negative impact of AVG applied in a single rate may be more accentuated on the red color of apples under anti-hail nets than in full sunlight. To minimize these effects, it is necessary to manage the application of AVG in order to delay the ripening of the fruits, without impairing the development of their red color. In this sense, the split application of
AVG, $62.5 \mathrm{mg} \mathrm{L}^{-1} 30 \mathrm{DBAH}+62.5 \mathrm{mg} \mathrm{L}^{-1} 20 \mathrm{DBAH}$, is an alternative treatment to delay ripening, without limiting the development of the red color of 'Baigent' apples grown under anti-hail nets.

The delay in harvesting resulted in redder fruits, with higher values for SS, the SS/TA ratio, and the iodine-starch index; however, it caused a reduction in TA, pulp firmness, and in the forces for pulp penetration and skin rupture, besides an increase in the degree of yellowing of the epidermis in the second harvest (Tables 2, 3, 4, and 5), characterizing a natural advance in fruit maturation, without changing the respiratory rate of the fruits.

Table 5. Hue angle $\left(h^{\circ}\right)$ evaluated in the most and least red regions, as well as red-color index, of fruits of 'Baigent' apple (Malus domestica) trees treated with the pre-harvest application of aminoethoxyvinilglycine (AVG) and ethephon, and harvested on two dates ${ }^{(1)}$.

\begin{tabular}{|c|c|c|c|c|c|c|}
\hline \multirow[t]{2}{*}{ Treatment } & \multicolumn{2}{|c|}{$2014 / 2015$ season } & \multirow[t]{2}{*}{ Average } & \multicolumn{2}{|c|}{$2015 / 2016$ season } & \multirow[t]{2}{*}{ Average } \\
\hline & Harvest 1 & Harvest 2 & & Harvest 1 & Harvest 2 & \\
\hline & \multicolumn{6}{|c|}{$h^{\circ}$ of the most red region } \\
\hline Control & $30.4 \mathrm{Ba}$ & $24.3 \mathrm{Bb}$ & - & 34.2 & 28.5 & $31.3 \mathrm{~B}$ \\
\hline $125 \mathrm{mg} \mathrm{L}^{-1}$ AVG $30 \mathrm{DBAH}$ & $32.2 \mathrm{ABa}$ & 29.4Aa & - & 58.0 & 41.9 & $50.0 \mathrm{~A}$ \\
\hline $120 \mathrm{mg} \mathrm{L}^{-1}$ ethephon $7 \mathrm{DBAH}$ & $28.0 \mathrm{Ba}$ & $23.7 \mathrm{Bb}$ & - & - & - & - \\
\hline $62.5 \mathrm{mg} \mathrm{L}^{-1} \mathrm{AVG} 30 \mathrm{DBAH}+62.5 \mathrm{mg} \mathrm{L}^{-1} \mathrm{AVG} 20 \mathrm{DBAH}$ & 35.4Aa & $27.4 \mathrm{ABb}$ & - & 48.5 & 37.7 & 41.9AB \\
\hline $\begin{array}{l}62.5 \mathrm{mg} \mathrm{L}^{-1} \text { AVG } 30 \mathrm{DBAH}+62.5 \mathrm{mg} \mathrm{L}^{-1} \mathrm{AVG} 20 \mathrm{DBAH} \\
+120 \mathrm{mg} \mathrm{L}^{-1} \text { ethephon } 7 \mathrm{DBAH}\end{array}$ & $36.6 \mathrm{Aa}$ & $26.5 \mathrm{ABb}$ & - & 44.8 & 32.0 & $38.4 \mathrm{~B}$ \\
\hline Average & - & - & & $46.1 \mathrm{a}$ & $35.0 \mathrm{~b}$ & \\
\hline \multirow[t]{2}{*}{ Coefficient of variation (\%) } & \multicolumn{2}{|c|}{7.2} & \multicolumn{4}{|c|}{15.5} \\
\hline & \multicolumn{6}{|c|}{$h^{\circ}$ of the least red region } \\
\hline Control & 85.3 & 59.8 & $72.5 \mathrm{~B}$ & 70.4 & 74.1 & $72.2 \mathrm{~B}$ \\
\hline $125 \mathrm{mg} \mathrm{L}^{-1}$ AVG $30 \mathrm{DBAH}$ & 94.8 & 69.9 & $82.4 \mathrm{~A}$ & 100.4 & 89.7 & $95.1 \mathrm{~A}$ \\
\hline $120 \mathrm{mg} \mathrm{L}^{-1}$ ethephon $7 \mathrm{DBAH}$ & 81.5 & 49.9 & $65.7 \mathrm{~B}$ & - & - & - \\
\hline $62.5 \mathrm{mg} \mathrm{L}^{-1} \mathrm{AVG} 30 \mathrm{DBAH}+62.5 \mathrm{mg} \mathrm{L}^{-1} \mathrm{AVG} 20 \mathrm{DBAH}$ & 81.9 & 62.6 & $72.2 \mathrm{~B}$ & 99.1 & 86.6 & $92.9 \mathrm{~A}$ \\
\hline $\begin{array}{l}62.5 \mathrm{mg} \mathrm{L}^{-1} \mathrm{AVG} 30 \mathrm{DBAH}+62.5 \mathrm{mg} \mathrm{L}^{-1} \mathrm{AVG} 20 \mathrm{DBAH} \\
+120 \mathrm{mg} \mathrm{L}^{-1} \text { ethephon } 7 \mathrm{DBAH}\end{array}$ & 79.7 & 56.9 & $68.3 \mathrm{~B}$ & 92.1 & 81.88 & $86.9 \mathrm{~A}$ \\
\hline Average & $84.6 \mathrm{a}$ & $59.8 b$ & & $90.5 \mathrm{a}$ & $83.0 \mathrm{~b}$ & \\
\hline \multirow[t]{2}{*}{ Coefficient of variation (\%) } & \multicolumn{2}{|c|}{9.3} & \multicolumn{4}{|c|}{7.7} \\
\hline & \multicolumn{6}{|c|}{ Red-color index (1 to 4) } \\
\hline Control & 2.5 & 4.0 & $3.3 \mathrm{~A}$ & 3.9 & 3.5 & $3.7 \mathrm{~A}$ \\
\hline $125 \mathrm{mg} \mathrm{L}^{-1} \mathrm{AVG} 30 \mathrm{DBAH}$ & 2.0 & 3.3 & $2.6 \mathrm{~B}$ & 2.4 & 2.6 & $2.5 \mathrm{~B}$ \\
\hline $120 \mathrm{mg} \mathrm{L}^{-1}$ ethephon 7 DBAH & 3.0 & 4.0 & $3.5 \mathrm{~A}$ & - & - & - \\
\hline $62.5 \mathrm{mg} \mathrm{L}^{-1} \mathrm{AVG} 30 \mathrm{DBAH}+62.5 \mathrm{mg} \mathrm{L}^{-1} \mathrm{AVG} 20 \mathrm{DBAH}$ & 2.3 & 4.0 & $3.1 \mathrm{AB}$ & 2.6 & 3.0 & $2.8 \mathrm{AB}$ \\
\hline $\begin{array}{l}62.5 \mathrm{mg} \mathrm{L}^{-1} \text { AVG } 30 \mathrm{DBAH}+62.5 \mathrm{mg} \mathrm{L}^{-1} \mathrm{AVG} 20 \mathrm{DBAH} \\
+120 \mathrm{mg} \mathrm{L}^{-1} \text { ethephon } 7 \mathrm{DBAH}\end{array}$ & 2.5 & 3.8 & $3.1 \mathrm{AB}$ & 3.0 & 3.5 & $3.3 \mathrm{AB}$ \\
\hline Average & $2.5 \mathrm{~b}$ & $3.8 \mathrm{a}$ & & $3.0 \mathrm{a}$ & $3.2 \mathrm{a}$ & \\
\hline Coefficient of variation (\%) & \multicolumn{2}{|c|}{12.0} & \multicolumn{4}{|c|}{19.6} \\
\hline
\end{tabular}

(1)Values followed by equal letters, uppercase in the columns and lowercase in the lines, do not differ by Tukey's test, at 5\% probability. DBAH, days before anticipated harvest time. Harvest 1, commercial harvest of the control treatment. Harvest 2, 14 days after commercial harvest of the control treatment. -, data not obtained. 


\section{Conclusions}

1. The application of aminoethoxyvinylglycine (AVG) in a single rate, regardless of the harvest date, delays the maturation of 'Baigent' apple (Malus domestica) fruits, but impairs the development of their red skin color.

2. The split application of AVG in combination with ethephon, regardless of the harvest date, is effective in delaying fruit maturation and does not affect the development of the red color of the epidermis of the fruits.

\section{Acknopwledgments}

To Conselho Nacional de Desenvolvimento Científico e Tecnológico (CNPq) and to Fundação de Amparo à Pesquisa e Inovação do Estado de Santa Catarina (Fapesc), for financial support and scholarship (CNPq process no. 427319/2018-8 and PAP-Fapesc/ Udesc process no. 2019TR950).

\section{References}

AMARANTE, C.V.T. do; STEFFENS, C.A.; MIQUELOTO, A.; ZANARDI, O.Z.; SANTOS, H.P. dos. Disponibilidade de luz em macieiras 'Fuji' cobertas com telas antigranizo e seus efeitos sobre a fotossíntese, o rendimento e a qualidade dos frutos. Revista Brasileira de Fruticultura, v.31, p.664-670, 2009. DOI: https:// doi.org/10.1590/S0100-29452009000300007.

ARGENTA, L.C.; MONDARDO, M. Maturação na colheita e qualidade de maçãs 'Gala' após a armazenagem. Revista Brasileira de Fisiologia Vegetal, v.6, p.135-140, 1994.

ARSENEAULT, M.H.; CLINE, J.A. A review of apple preharvest fruit drop and practices for horticultural management. Scientia Horticulturae, v.211, p.40-52, 2016 DOI: https://doi.org/10.1016/j. scienta.2016.08.002.

AWAD, M.A.; de JAGER, A. Formation of flavonoids, especially anthocyanin and chlorogenic acid in 'Jonagold' apple skin: influences of growth regulators and fruit maturity. Scientia Horticulturae, v.93, p.257-266, 2002. DOI: https://doi.org/10.1016/S0304-4238(01)00333-8.

BOTH, V.; THEWES, F.R.; BRACKMANN, A.; FERREIRA, D. de F.; PAVANELLO, E.P.; WAGNER, R. Effect of low oxygen conditioning and ultralow oxygen storage on the volatile profile, ethylene production and respiration rate of 'Royal Gala' apples. Scientia Horticulturae, v.209, p.156-164. 2016. DOI: https://doi.org/10.1016/j.scienta.2016.06.028.

BRACKMANN, A.; THEWES, F.R.; ANESE, R. de O.; BOTH, V. Effect of growth regulators on 'Brookfield' apple gas diffusion and metabolism under controlled atmosphere storage.
Pesquisa Agropecuária Brasileira, v.49, p.323-329, 2014. DOI: https://doi.org/10.1590/S0100-204X2014000500001.

BRACKMANN, A.; THEWES, F.R.; ANESE, R. de O.; BOTH, V.; LINKE JUNIOR, W.; SCHULTZ, E.E. Aminoethoxyvinylglycine: isolated and combined with other growth regulators on quality of 'Brookfield' apples after storage. Scientia Horticulturae, v.72, p.221-228, 2015a. DOI: https://doi.org/10.1590/0103-9016-20140099 .

BRACKMANN, A.; THEWES, F.R.; SANTOS, L.F. dos; MACHADO, E.P.; LUDWIG, V.; ARTMANN, L. da S. Effect of growth regulators application on the quality maintenance of 'Brookfield' apples. Bragantia, v.74, p.453-456, 2015b. DOI: https://doi.org/10.1590/1678-4499.0050.

BRGLEZ SEVER, M.; TOJNKO, S.; UNUK, T. Impact of various types of anti-hail nets on light exposure in orchards and quality parameters of apples - a rewiev. Agricultura, v.12, p.25-31, 2015. DOI: https://doi.org/10.1515/agricultura-2016-0004.

BRIGHENTI, F.A.; WÜRZ, D.A.; PASA, M. da S.; RUFATO, L. Plant growth regulators to enhance fruit color of 'Gala' apples. Pesquisa Agropecuária Brasileira, v.52, p.1118-1122, 2017. DOI: https://doi.org/10.1590/s0100-204x2017001100018.

DROGOUDI, P.D.; PANTELIDIS, G. Effects of position on canopy and harvest time on fruit physico-chemical and antioxidant properties in different apple cultivars. Scientia Horticulturae, v.129, p.752-760, 2011. DOI: https://doi.org/10.1016/j.scienta.2011.05.036.

GUILLERMIN, P.; DUPONT, N.; LE MORVAN, C.; LE QUÉRÉ, J.-M.; LANGLAIS, C.; MAUGET, J.C. Rheological and technological properties of two cider apple cultivars. LWT - Food Science and Technology, v.39, p.995-1000, 2006. DOI: https://doi.org/10.1016/j.lwt.2006.02.025.

HAWERROTH, F.J.; PETRI, J.L.; LEITE, G.B.; COUTO, M. Uso de aminoetoxivinilglicina na maturação e queda pré-colheita de maçãs 'Imperial Gala'. Revista Ceres, v.58, p.612-618, 2011. DOI: https://doi.org/10.1590/S0034-737X2011000500011.

MUNARETTO, L.M.; BOTELHO, R.V.; RESENDE, J.T.V.; SCHWARZ, K.; SATO, A.J. Productivity and quality of organic strawberries pre-harvest treated with silicon. Horticultura Brasileira, v.36, p.40-46, 2018. DOI: https://doi.org/10.1590/ s0102-053620180107.

MUPAMBI, G.; ANTHONY, B.M.; LAYNE, D.R.; MUSACCHI, S.; SERRA, S.; SCHMIDT, T.; KALCSITS, L.A. The influence of protective netting on tree physiology and fruit quality of apple: a review. Scientia Horticulturae, v.236, p.60-72, 2018. DOI: https://doi.org/10.1016/j.scienta.2018.03.014.

OZKAN, Y.; ALTUNTAS, E.; OZTURK, B.; YILDIZ, K.; SARACOGLU, O. The effect of NAA (1-naphthalene acetic acid) and AVG (aminoethoxyvinylglycine) on physical, chemical, colour and mechanical properties of Braeburn apple. International Journal of Food Engineering, v.8, art.17, 2012. DOI: https://oi.org/10.1515/1556-3758.2524.

OZTURK, B.; OZKAN, Y.; YILDIZ, K. AVG application regimes play an important role on pre-harvest drop and ripening of 'Jonagold' apples. Semina: Ciências Agrárias, v.36, p.3595-3604, 2015. DOI: https://doi.org/10.5433/1679-0359.2015v36n6p3595. 
PETRI, J.L.; HAWERROTH, F.J.; LEITE, G.B. Maturação, qualidade e queda pré-colheita de maçãs 'Imperial Gala' em função da aplicação de aminoetoxivinilglicina. Bragantia, v.69, p.599-608, 2010. DOI: https://doi.org/10.1590/S000687052010000300011 .

SANTOS, H.G. dos; JACOMINE, P.K.T.; ANJOS, L.H.C. dos; OLIVEIRA, V.Á. de; LUMBRERAS, J.F.; COELHO, M.R.; ALMEIDA, J.A. de; ARAÚJO FILHO, J.C. de; OLIVEIRA, J.B. de; CUNHA, T.J.F. Sistema brasileiro de classificação de solos. 5.ed. rev. e ampl. Brasília: Embrapa, 2018. 356p.

SCOLARO, A.M.T.; ARGENTA, L.C.; AMARANTE, C.V.T. do; PETRI, J.L.; HAWERROTH, F.J. Controle da maturação précolheita de maçãs 'Royal Gala' pela inibição da ação ou síntese do etileno. Revista Brasileira de Fruticultura, v.37, p.38-47, 2015. DOI: https://doi.org/10.1590/0100-2945-010/14.

SOETHE, C.; STEFFENS, C.A.; HAWERROTH, F.J.; AMARANTE, C.V.T. do; HEINZEN, A.S.; STANGER, M.C. Postharvest quality of 'Baigent' apples as a function of single and multiple preharvest spray aminoetoxivinylglycine and ethephon applications. Revista Brasileira de Fruticultura, v.41, e-153, 2019. DOI: https://doi.org/10.1590/0100-29452019153.

SOIL SURVEY STAFF. Keys to soil taxonomy. 11th ed. Washington: USDA, NRCS, 2010.

STANGER, M.C.; STEFFENS, C.A.; SOETHE, C.; MOREIRA, M.A.; AMARANTE, C.V.T. do. Phenolic content and antioxidant activity during the development of 'Brookfield' and 'Mishima' apples. Journal of Agricultural and Food Chemistry, v.65, p.3453-3459, 2017. DOI: https://doi.org/10.1021/acs.jafc.6b04695.

STEFFENS, C.A.; AMARANTE, C.V.T. do; CHECHI, R.; ZANARDI, O.Z.; ESPINDOLA, B.P.; MENEGHINI, A.L. O tratamento pré-colheita com aminoetoxivinilglicina ou ácido giberélico preserva a qualidade pós-colheita de ameixas 'Laetitia'. Bragantia, v.70, p.222-227, 2011. DOI: https://doi.org/10.1590/ S0006-87052011000100029.
STEFFENS, C.A.; BRACKMANN, A.; PINTO, J.A.V.; EISERMANN, A.C. Taxa respiratória de frutas de clima temperado. Pesquisa Agropecuária Brasileira, v.42, p.313-321, 2007. DOI: https://doi.org/10.1590/S0100-204X2007000300003.

STEFFENS, C.A.; GUARIENTI, A.J.W.; STORCK, L.; BRACKMANN, A. Maturação da maçã 'Gala' com a aplicação pré-colheita de aminoetoxivinilglicina e ethephon. Ciência Rural, v.36, p.434-440, 2006. DOI: https://doi.org/10.1590/S010384782006000200012 .

WENDT, L.M.; BRACKMANN, A.; BOTH, V.; THEWES, F.R.; SCHULTZ, E.E.; LUDWIG, V.; BERGHETTI, M.R.P. Postharvest quality of 'Brookfield' apple field-treated with naphthalene acetic acid alone or combined with other growth regulators. Bragantia, v.79, p.155-168, 2020. DOI: https://doi.org/10.1590/1678-4499.20190194.

WHALE, S.K.; SINGH, Z. Endogenous ethylene and color development in the skin of 'Pink Lady' apple. Journal of the American Society for Horticultural Science, v.132, p.20-28, 2007. DOI: https://doi.org/10.21273/JASHS.132.1.20.

YILDIZ, K.; OZTURK, B.; OZKAN, Y. Effects of aminoethoxyvinylglycine (AVG) on preharvest fruit drop, fruit maturity, and quality of 'Red Chief' apple. Scientia Horticulturae, v.144, p.121-124, 2012. DOI: https://doi.org/10.1016/j.scienta.2012.07.005.

YUAN, R.; CARBAUGH, D.H. Effects of ANA, AVG, and 1-MCP on ethylene biosynthesis, preharvest fruit drop, fruit maturity and quality of 'Golden Supreme' and 'Golden Delicious' apples. HortScience, v.42, p.101-105, 2007. DOI: https://doi.org/10.21273/ HORTSCI.42.1.101.

ZHENG, H.-Z.; KIM, Y.-I.; CHUNG, S.-K. A profile of physicochemical and antioxidant changes during fruit growth for the utilisation of unripe apples. Food Chemistry, v.131, p.106-110, 2012. DOI: https://doi.org/10.1016/j.foodchem.2011.08.038. 